ARTYKUtY Prawo i administracja Unii Europejskiej / Law and Administration

of the European Union

DOI 10.4467/24497800RAP.18.003.9218

http://www.ejournals.eu/RAP/

ISSN 2449-7800 (online), ISSN 2449-7797 (druk), s. 47-66

Justyna Holocher, Bogumlt NalezlŃSKI'

\title{
Konstytucyjne determinanty stosowania prawa Unii Europejskiej przez organy władzy sądowniczej w Rzeczypospolitej Polskiej
}

\section{Założenia wstępne}

Przedmiotem poniższych rozważań jest analiza konstytucyjnie zdeterminowanego zjawiska stosowania prawa Unii Europejskiej przez organy, które z woli polskiego ustrojodawcy zaliczone został do tzw. trzeciej władzy, a więc przez sądy i trybunały (art. 10 ust. 2 Konstytucji ${ }^{2}$ ). Warto podkreślić, że ograniczenie analiz wyłącznie do tych dwóch kategorii organów nie oznacza całkowitego pozostawienia poza jej ramami także innych instytucji władzy publicznej, takich jak np. organy administracji. Po pierwsze, wynika to $\mathrm{z}$ faktu objęcia również ich zakresem zastosowania niektórych $\mathrm{z}$ unormowań uwzględnionych jako tytułowe determinanty (np. art. 91 ust. 2 i 3 Konstytucji). Po drugie, jest to konsekwencja funkcjonalnych zależności zachodzących między organami państwa (np. sądowa kontrola działalności administracji publicznej - art. 184 Konstytucji), które w pełni uzasadniają przeniesienie formułowanych tez i wniosków także na innych aniżeli organy władzy sądowniczej adresatów norm prawa UE.

Poddając analizie problem stosowania prawa, należy odwołać się $\mathrm{w}$ pierwszym rzędzie do sformułowanych $\mathrm{w}$ teorii prawa definicji tego pojęcia, zwłaszcza tych, w oparciu o które konstruowany jest model tzw. sądowego stosowania prawa ${ }^{3}$. Zarówno jednak szczególne właściwości samego prawa UE i jego miejsce w systemie źródeł, jak i specyfika działalności orzeczniczej sądu konstytucyjnego uzasadniają szersze aniżeli tylko wynikające z tego modelu spojrzenie na przedmiot działalności orzeczniczej organów stosujących normy należące do tego segmentu obowiązującego prawa.

Rozważania zawarte $\mathrm{w}$ niniejszym opracowaniu determinuje perspektywa krajowa, tym samym prowadzone są one w świetle zasad wyrażonych

${ }^{1}$ Dr Justyna Holocher, dr Bogumił Naleziński, Uniwersytet Pedagogiczny im. KEN w Krakowie, Instytut Politologii, Katedra Instytucji Politycznych i Prawnych.

${ }^{2}$ Konstytucja Rzeczypospolitej Polskiej z dnia 2 kwietnia 1997 r., Dz.U. Nr 78, poz. 483 ze zm.

${ }^{3}$ J. Wróblewski, Sądowe stosowanie prawa, Warszawa 1988. 
w Konstytucji państwa będącego członkiem UE, nie zaś - przynajmniej bezpośrednio - w oparciu o nakazy i zakazy wynikające $\mathrm{z}$ unormowań samego prawa UE. Jest to istotne zastrzeżenie, choćby $\mathrm{z}$ uwagi na ujawnione w funkcjonowaniu UE i jej państw członkowskich dylematy dotyczące zasady pierwszeństwa prawa UE przed konstytucjami krajowymi czy też problemu kognicji sądów konstytucyjnych państw członkowskich w odniesieniu do aktów prawa stanowionych przez organizację międzynarodową, do której państwa te przystąpily.

Ujęcie prawa UE jako przedmiotu rozważań zasadniczo nie uwzględnia jego wewnętrznego zróżnicowania (zwłaszcza w sferze aktów tzw. prawa pochodnego), tym niemniej w pewnych elementach analizy, zwłaszcza odwołującej się do jednoznacznej treści norm konstytucyjnych (np. art. 90 oraz 91 ust. 2 i 3 Konstytucji) niezbędne okaże się odrębne potraktowanie prawa pierwotnego i prawa pochodnego UE.

Sekwencja prowadzonych rozważań uwzględnia w pierwszym rzędzie elementy wspólne dla problemów stosowania prawa UE, zarówno przez sądy, jak i trybunały. W dalszej kolejności analizie poddane zostały problemy odrębne dla obydwu segmentów władzy sądowniczej, także z rozdzieleniem poszczególnych jej organów, tzn. Trybunału Konstytucyjnego i Trybunału Stanu.

Celem niniejszego opracowania jest zaś próba odpowiedzi na pytanie o stopień możliwej modyfikacji wykonywania przez organy judykatywy przypisanych im kompetencji orzeczniczych, wywołanej powinnością stosowania także prawa UE. Interesująca wydaje się zwłaszcza odpowiedź na pytanie o zakres ewentualnego „uwolnienia” sędziów rozstrzygających $\mathrm{w}$ indywidualnych sprawach od bezwzględnego związania treścią norm prawa krajowego (przede wszystkim dekodowanych z ustaw). Za swoiste motto dla przedstawionej analizy służyć zaś może następująca wypowiedź jednego z sędziów francuskich: „największym wpływem prawa wspólnotowego było uwolnienie sędziego [francuskiego - J.H., B.N.] od całkowitego podporządkowania swojemu własnemu prawu, (...) dla sędziego prawo wspólnotowe było narzędziem emancypacji" - Guy Canivet (I Prezes Trybunału Kasacyjnego we Francji $)^{4}$.

\section{Prawo wspólnotowe a prawo krajowe}

\subsection{Wspólnotowa perspektywa wzajemnych relacji porządków prawnych}

Rekonstrukcja zasad rządzących miejscem prawa UE w systemie źródeł prawa polskiego wymaga kilku słów komentarza na temat charakteru

${ }^{4}$ Cyt. za: A. Frąckowiak-Adamska, Kompetencja do niezastosowania przez sędziego krajowego przepisu ustawy niezgodnego z Konstytucja lub prawem wspólnotowym [w:] Stosowanie prawa wspólnotowego w prawie wewnętrznym $z$ uwzględnieniem prawa polskiego, D. Kornobis-Romanowska (red.), Warszawa 2004, s. 193. 
i specyfiki prawa europejskiego oraz miejsca zajmowanego przez to prawo w krajowych systemach prawnych. Jest to tym bardziej uzasadnione, że jego geneza oraz natura są przy ustalaniu wzajemnych relacji dwóch porządków prawnych istotnymi argumentami. Przyjmuje się, co wielokrotnie potwierdzone zostało w orzecznictwie wspólnotowym, że prawo europejskie stanowi własny, autonomiczny porządek prawny, który został włączony do porządków prawnych państw członkowskich i musi być, jako źródło praw i obowiązków dla podmiotów prawnych, jednolicie stosowany przez ich sądy ${ }^{5}$.

Z punktu widzenia prawa unijnego o zakresie obowiązywania tego prawa nie decydują porządki krajowe (konstytucje narodowe) państw członkowskich, lecz samo prawo UE ${ }^{6}$. To zaś zakłada jego pierwszeństwo ${ }^{7}$ $\mathrm{w}$ stosunku do prawa krajowego, co oznacza, że norma prawa unijnego w zakresie swojego działania wykazuje pierwszeństwo w przypadku kolizji z normą prawa krajowego, bez względu na hierarchię krajowego aktu prawnego oraz chwilę jego wejścia w życie. A więc każda kolizja normy unijnej z normą krajową musi być rozstrzygana na korzyść tej pierwszej. Wynika to z faktu, że „każda norma wspólnotowa od momentu jej wejścia w życie, czyni automatycznie niemożliwą do zastosowania każdą sprzeczną z nią normę prawa krajowego"'. Konsekwencją prymatu prawa UE nie

${ }^{5}$ Wyrok TS z dnia 15 lipca 1964 r. w sprawie 6/64, Flaminio Costa v. E.N.E.L., ECR 1964, s. 614; wyrok TS z dnia 5 lutego 1963 r. w sprawie 26/62, N.V. Algemene Transport-en Expeditie Onderneming van Gend \& Loos v. Nederlandse administratie der belastingen, ECR 1963, s. 1; C. Mik, Powierzenie Unii Europejskiej władzy przez państwa członkowskie i jego podstawowe konsekwencje prawne [w:] Suwerenność i ponadnarodowość a integracja europejska, J. Kranz (red.), Warszawa 2006, s. 121 i n.

${ }^{6}$ P. Kapusta, Sad krajowy jako sąd unijny [w:] Zasada pierwszeństwa prawa Unii Europejskiej w praktyce działania organów władzy publicznej RP, M. Jabłoński i S. Jarosz-Żukowska (red.), Wrocław 2015, s. 231, http://www.repozytorium.uni.wroc.pl/ Content/64532/13_Piotr_Kapusta.pdf (1.12.2017).

${ }^{7}$ Orzeczenia dotyczące zasady pierwszeństwa prawa UE: wyrok w sprawie 6/64, Costa v. ENEL (1964); wyrok z dnia 17 grudnia 1970 r. w sprawie 11/70, Internationale Handelsgesellschaft $m b H$ v. Einfuhr- und Vorratsstelle für Getreide und Futtermittel, ECR 1970, vol. 2, s. 112; wyrok z dnia 9 marca 1978 r. w sprawie 106/77, Amministrazione delle Finanze dello Stato v. Simmenthal S.p.A., ECR 1978, vol. 3, s. 629. Stanowisko trybunałów konstytucyjnych państw członkowskich: orzeczenia niemieckiego Federalnego Trybunału Konstytucyjnego (BVG): wyrok z dnia 28 maja 1974 r. w sprawie 37/271, Solange I; wyrok z dnia 26 października 1986 r. w sprawie 73/339, Solange II; wyrok z dnia 12 października 1993 r. w sprawie 89/155, Maastricht; wyrok z dnia 30 czerwca 2009 r. w sprawie 2/08, Lissabon-Urteil oraz wyrok z dnia 6 lipca 2010 r. w sprawie 2661/06, Honeywell. Stanowisko polskiego TK: wyrok z dnia 11 maja 2005 r., K 18/04, Dz.U. Nr 86, poz. 744 (Traktat Akcesyjny), wyrok z dnia 24 listopada 2010 r., K 32/09, Dz.U. Nr 229, poz. 1506 (ratyfikacja Traktatu z Lizbony), wyrok z dnia 16 listopada 2011 r., SK 45/09, Dz.U. Nr 254, poz. 1530 (jurysdykcja i uznawanie orzeczeń sądowych oraz ich wykonywanie w sprawach cywilnych i handlowych).

${ }^{8}$ Wyrok TS w sprawie 106/77, Simmenthal. 
jest zatem nieważność sprzecznego z nim prawa krajowego, lecz obowiązek niestosowania normy krajowej ${ }^{9}$. Prymat prawa UE nie jest więc tutaj prymatem obowiązywania, lecz stosowania. Wywołuje jednak oczywiście również skutki w sferze obowiązywania, mianowicie prawo wspólnotowe wynikające $\mathrm{z}$ Traktatu, jako niezależnego źródła prawa, ze względu na swą istotę nie może być uchylone przez przepisy prawa krajowego, i to niezależnie od ich rangi, a ponadto wejście w życie nowej normy prawa wewnętrznego jest niemożliwe $\mathrm{w}$ takim zakresie, $\mathrm{w}$ jakim byłaby ona sprzeczna $\mathrm{z}$ normami unijnymi ${ }^{10}$.

\subsection{Krajowa perspektywa wzajemnych relacji porządków prawnych}

W świetle dość lakonicznych unormowań Konstytucji oraz tez wypowiedzianych $\mathrm{w}$ orzecznictwie Trybunału Konstytucyjnego podstawowe znaczenie dla wzajemnych relacji obydwu porządków prawnych mają przede wszystkim art. 8, 9, 90 oraz 91 ust. 2 i 3 Konstytucji. Odnoszą się one do hierarchii aktów prawnych w systemie prawa (art. 8 ust. 1) oraz wskazują na obowiązek przestrzegania prawa międzynarodowego (art. 9), tak pierwotnego, jak i pochodnego, które na podstawie uprzedniego przekazania UE kompetencji prawodawczych stały się częścią porządku prawnego RP. Konstytucja rozróżnia prawo międzynarodowe w postaci ratyfikowanej umowy międzynarodowej oraz prawo stanowione przez organizację międzynarodową (w tym także prawo wspólnotowe pochodne), wskazując miejsce tak rozumianego prawa międzynarodowego w systemie źródeł prawa obowiązującego. Jest to wyraz konstytucyjnej akceptacji współobowiązywania w systemie prawnym (genetycznie i rodzajowo) norm prawnych spoza wewnętrznego porządku prawnego, określanej często mianem multicentryczności ${ }^{11}$. Pierwszeństwo przed prawem unijnym, tak pierwotnym (ratyfikowanymi za uprzednią zgodą umowami międzynarodowymi), jak i pochodnym (prawem stanowionym przez organy Wspólnoty), ustrojodawca wyraźnie zastrzega jednak dla Konstytucji. Nie dotyczy to już aktów niższego rządu, które w przypadku kolizji z umowami międzynarodowymi ratyfikowanymi za uprzednią zgodą wyrażoną $\mathrm{w}$ ustawie i prawem stanowionym przez utworzone na ich podstawie organizacje międzynarodowe muszą im ustąpić (art. 90, 91 ust. 2 i 3 Konstytucji).

${ }^{9}$ Wyrok TS z dnia 19 listopada 2009 r. w sprawie C-314/08, Krzysztof Filipiak v. Dyrektor Izby Skarbowej w Poznaniu, ECR 2009, vol. 11, s. I-11049.

${ }^{10}$ TS w sprawie 106/77, Simmenthal.

${ }^{11}$ Wyrok TK K 18/04; zob. E. Łętowska, Multicentryczność wspótczesnego systemu prawa $i$ wykładnia jej przyjazna [w:] Rozprawy prawnicze. Ksiega pamiatkowa Profesora Maksymiliana Pazdana, L. Ogiegło, W. Popiołek, M. Szpunar (red.), Kraków 2002, s. 1127; A. Kalisz, Muliticentryczność systemu prawa polskiego a działalność orzecznicza Europejskiego Trybunału Sprawiedliwości i Europejskiego Trybunału Praw Człowieka, „Ruch Prawniczy, Ekonomiczny i Socjologiczny” 2007, rok LXIX, z. 4, s. 35-47. 
Zasadę prymatu ustawy zasadniczej Trybunał Konstytucyjny podkreślił wyraźnie w wyroku z dnia 11 maja 2005 r., K 18/04 w sprawie Traktatu Akcesyjnego, stwierdzając, że ,art. 8 ust. 1 Konstytucji jednoznacznie gwarantuje postanowieniom Konstytucji status "najwyższego prawa Rzeczypospolitej Polskiej «". Konsekwencją tej normy jest niedopuszczalność zakwestionowania mocy obowiązującej normy konstytucyjnej przez sam fakt wprowadzenia do systemu prawa europejskiego sprzecznej z nią regulacji wspólnotowej. Innymi słowy, jak podnosi dalej Trybunał, legitymacja prawa unijnego w systemach prawnych państw członkowskich, która wynika z ograniczenia kompetencji państw członkowskich w niektórych sprawach i przeniesienia uprawnień tych państw do ich wykonywania na rzecz Unii, nie rozciąga się na Konstytucję. „Błędny jest pogląd, iż przez ratyfikację traktatu akcesyjnego uchylono nadrzędność Konstytucji RP, zastępując ją traktatową zasadą pierwszeństwa prawa wspólnotowego, gdyż miałaby za tym przemawiać także treść art. 9 Konstytucji”" ${ }^{12}$, stanowiącego, że Rzeczpospolita Polska przestrzega wiążącego ją prawa międzynarodowego.

Przyjmuje się, że w sferze prawa międzynarodowego art. 9 ma charakter wyłącznie deklaratywny. Jednakże w sferze prawa krajowego ma funkcję konstytutywną w tym sensie, iż jest generalną podstawą otwarcia się na prawo międzynarodowe, wyrażającą równocześnie obowiązek jego stosowania ${ }^{13}$. Konstytucja nie wprowadza tutaj żadnej dystynkcji, art. 9 nie różnicuje źródeł prawa międzynarodowego, odnosi się więc do całości prawa międzynarodowego (lege non distinguente nec nostrum est distinguere), tak pierwotnego, jak i pochodnego. Jego postanowienia stwarzają domniemanie pośredniej inkorporacji wszystkich norm prawa międzynarodowego, także zwyczajowego, do krajowego porządku prawnego, rozszerzając dyspozycję normy z art. 7 Konstytucji, przewidującego obowiązek organów władzy państwowej działania na podstawie i w granicach prawa, w tym na podstawie prawa wspólnotowego.

Obowiązek ten nie ma jednak charakteru absolutnego. Ogranicza go przywołana już zasada nadrzędności Konstytucji. Tak więc w przypadku zaistnienia nieusuwalnej w drodze wykładni kolizji pomiędzy postanowieniami Konstytucji a regulacjami prawa wspólnotowego, nie może być ona, jak wskazał Trybunał Konstytucyjny, „w żadnym razie rozwiązywana przez uznanie nadrzędności normy wspólnotowej w relacji do normy konstytucyjnej. Nie mogłaby też prowadzić do utraty mocy obowiązującej normy konstytucyjnej i zastąpienia jej normą wspólnotową ani do ograniczenia zakresu stosowania tej normy do obszaru, który nie został objęty regulacją prawa wspólnotowego. W takiej sytuacji do polskiego ustawodawcy należałoby podjęcie decyzji albo o zmianie Konstytucji, albo o spowodowaniu

${ }^{12}$ K. Pawłowicz, Konstytucja europejska - źródło nieustających emocji. Nie ma praw oczywistych - polemika, „Rzeczpospolita” z 28 czerwca 2004 r., s. 3.

${ }^{13}$ A. Wasilkowski, Miejsce umów międzynarodowych wedle nowej Konstytucji RP, „Przegląd Legislacyjny” 1997, nr 2, s. 29-39. 
zmian w regulacjach wspólnotowych, albo - ostatecznie - decyzji o wystąpieniu z Unii Europejskiej. Decyzję tę winien podjąć suweren, którym jest Naród Polski, lub organ władzy państwowej, który w zgodzie z Konstytucją może Naród reprezentować. Normy Konstytucji w dziedzinie praw i wolności jednostki wyznaczają minimalny i nieprzekraczalny próg, który nie może ulec obniżeniu ani zakwestionowaniu na skutek wprowadzenia regulacji wspólnotowych. Konstytucja pełni w tym zakresie swą rolę gwarancyjną, z punktu widzenia ochrony praw i wolności w niej wyraźnie określonych, i to w stosunku do wszystkich podmiotów czynnych w sferze jej stosowania"14.

Powyższe rozważania uzasadniają twierdzenie, że w zakresie obrony prymatu Konstytucji i ochrony zawartych w niej zasad stanowisko prezentowane w orzecznictwie TK pozostaje w duchu orzeczeń niemieckiego sądu konstytucyjnego (Solange), czyniąc z zasad konstytucyjnych swego rodzaju gwarancję „minimum moralnego”.

Podsumowując, treść art. 9 znajduje się w hierarchii konstytucyjnych zasad ustrojowych niżej niż zasada statuowana w art. 8, zgodnie z którą Konstytucja RP jest najwyższym prawem w Polsce. Oznacza to, że Polska przestrzega wiążącego ją prawa międzynarodowego, ale tylko w granicach konstytucji, a nie wbrew lub przeciw niej ${ }^{15}$. Podkreśla się, że sama Konstytucja jest źródłem zobowiązania państwa do wywiązania się ze zobowiązań międzynarodowych, oczywiście pod warunkiem, że przekazanie kompetencji na rzecz UE nastąpiło zgodnie $z$ jej literą ${ }^{16}$.

W związku ze zobowiązaniem do stosowania prawa wspólnotowego wskazać należy także na jego wyjątkowy zakres wynikający z konieczności respektowania acquis communautaire, które powstało przed przystąpieniem RP do struktur europejskich. Z orzecznictwa Sądu Najwyższego i Trybunału Konstytucyjnego można wyprowadzić ogólną regułę, że także w odniesieniu do stanów faktycznych poprzedzających przystąpienie Polski do Unii Europejskiej sąd w razie dysponowania kilkoma możliwościami interpretacji przepisów stosowanych do oceny sprawy powinien wybrać wykładnię najbliższą dorobkowi wspólnotowemu (acquis communautaire, zob. np. wyrok SN z dnia 29 listopada 2005 r., II PK 100/05 ${ }^{17}$ i powołane tam wcześniejsze orzecznictwo $)^{18}$. Zasada ta, u podstaw której leży zapewnienie jednolitego stosowania prawa europejskiego, przeczy zwykle przyjmowanym czasowym regułom stosowania i wykładni prawa.

${ }^{14}$ Wyrok TK K 18/04.

${ }^{15}$ Ibidem.

${ }^{16}$ W. Czapliński, Prawo wspólnotowe a prawo wewnętrzne w praktyce sądów konstytucyjnych państw członkowskich (wybrane zagadnienia), „Kwartalnik Prawa Publicznego" 2004, nr 2, s. 7.

${ }^{17}$ OSNP 2006, nr 19-20, poz. 299.

${ }^{18}$ Wyrok SN z dnia 7 lutego 2007 r., I PK 269/06, OSP 2009, z. 1, poz. 11. 


\subsection{Prowspólnotowa wykładnia prawa krajowego}

Respektowanie prawa UE jest rozumiane nie tylko jako jego bezpośrednie stosowanie, ale także jako nakaz stosowania prowspólnotowej wykładni prawa krajowego. Punktem wyjścia jest założenie, że prawo wspólnotowe i prawo krajowe powinny koegzystować na zasadzie obopólnie przyjaznej wykładni i kooperatywnego współstosowania ${ }^{19}$. Dotyczy to wszystkich organów krajowych i wszystkich krajowych przepisów prawnych. Jest nieodłączną cechą systemu traktatowego, umożliwiającą organom stosującym prawo zapewnienie $\mathrm{w}$ ramach ich właściwości pełnej skuteczności prawa UE. Obowiązek dokonywania prowspólnotowej wykładni prawa sprowadza się do interpretowania przepisów krajowych w świetle brzmienia i celów norm prawa UE, innymi słowy, jest to obowiązek nadania regulacji prawa wewnętrznego takiego sensu normatywnego, który będzie pozostawał w zgodzie z porządkiem prawnym Wspólnoty. Dyrektywy wykładni sprowadzają się tu do zakazu podważania podstaw prawnych Wspólnoty oraz nakazu pełnego i jednolitego stosowania prawa UE. Wykładnia ta jest jednak ograniczona przez ogólne zasady prawa, w szczególności zasady pewności prawa i braku retroaktywności prawa, a ponadto nie może służyć jako podstawa do dokonywania wykładni prawa krajowego contra legem ${ }^{20}$. W żadnej sytuacji nie może więc prowadzić do rezultatów sprzecznych z wyraźnym brzmieniem norm konstytucyjnych i niemożliwych do uzgodnienia z minimum funkcji gwarancyjnych realizowanych przez Konstytucję ${ }^{21}$.

Podsumowując, z obowiązku przeprowadzania prowspólnotowej wykładni wynika nakaz kierowany w stronę organów stosujących prawo, aby podejmowały wszelkie działania w zakresie swych kompetencji, uwzględniając wszystkie przepisy prawa krajowego i stosując uznane w porządku krajowym metody wykładni, by zapewnić pełną skuteczność prawa europejskiego. Skuteczność tę należy rozumieć jako urzeczywistnienie idei, celu oraz treści prawa UE. Podkreślić przy tym należy, że konsekwencją jego naruszeń (w tym także niewłaściwej interpretacji) jest odpowiedzialność odszkodowawcza. W świetle dotychczasowego orzecznictwa Trybunału Sprawiedliwości UE odpowiedzialność ta dotyczy zarówno działania władzy ustawodawczej (Brasserie, Factortame ${ }^{22}$ oraz Francovich ${ }^{23}$ ), wykonawczej,

${ }^{19}$ Wyrok TK z dnia 11 maja 2005 r., K 18/04.

${ }^{20}$ Wyrok SN z dnia 11 grudnia 2014 r., I PK 120/14, LEX nr 1628903; wyrok TS z dnia 14 lipca 1994 r. w sprawie C-91/92, Paola Faccini Dori v. Recreb Srl, ECR 1994, vol. 7, s. I-3325.

${ }^{21}$ Wyrok TK K $18 / 04$.

${ }^{22}$ Wyrok TS z dnia 5 marca 1996 r. w sprawach połączonych C46/93 i C48/93, Brasserie du Pecheur SA v. Republika Federalna Niemiec $i$ The Queen v. Secretary of State for Transport, ex parte Factortame Ltd i inni, ECR 1996, vol. 3, s. I-1029.

${ }^{23}$ Wyrok TS z dnia 19 listopada 1991 r. w sprawach C6/90 i C9/90, Andrea Francovich i inni v. Republika Włoska, ECR 1991, vol. 9, s. I-5357. 
jak i sądowniczej $\left(K_{\text {Koebler }}^{24}\right)$. Trybunał stosuje interpretację funkcjonalną zasady odpowiedzialności, uznając, że mogą to być władze regionalne w państwie federalnym (Konle ${ }^{25}$ ), a także podmioty o odrębnej od państwa podmiotowości publicznoprawnej, np. samorząd zawodowy $\left(\right.$ Haim $\left.^{26}\right)$. Szerokie rozumienie państwa oznacza, że nieistotne jest, czy działa ono w sferze prywatnoprawnej czy publicznoprawnej.

\subsection{Znaczenie zasady podziału i równowagi władz (art. 10), niezależności „trzeciej władzy" (art. 173) i autonomii proceduralnej z punktu widzenia wymogów stawianych przez prawo UE}

Obowiązywanie prawa UE (zgoda na jego treść i sposób oddziaływania na porządek prawny) ma nie tylko wpływ na rozumienie i stosowanie zasad dotyczących źródeł prawa oraz hierarchii aktów normatywnych, ale także tych, które odnoszą się do aspektu instytucjonalno-procesowego. Związane jest to $\mathrm{z}$ funkcjami tradycyjnie przypisywanymi poszczególnym organom państwa oraz gwarancjami, które mają zapewniać należyte ich realizowanie. Chodzi tutaj przede wszystkim o konstytucyjną zasadę podziału władzy (art. 10) oraz o zasadę wyrażoną w art. 173 Konstytucji, zgodnie z którymi sądy i Trybunały są władzą odrębną i niezależną od innych władz. $\mathrm{Z}$ uwagi na treść tych norm powstaje pytanie, na ile porządek prawa UE oraz zasady jego tworzenia i stosowania wpływają na konstytucyjne relacje władz i wykonywane przez nie zadania. Czy prawo UE ma wpływ na rozwiązania instytucjonalne i proceduralne? Czy można mówić o pewnych ograniczeniach wynikających z założeń i celów tego prawa, dotykających prawodawcę oraz organy, które je stosują?

Najogólniej rzecz ujmując, w zakresie rozwiązań instytucjonalnych i proceduralnych, a więc organizacji wymiaru sprawiedliwości i kształtu procedury, zachowana została względna autonomia państw członkowskich. Względność ta polega na ograniczeniu swobody państw fundamentalnymi zasadami, które zagwarantować mają „wspólnotowo” akceptowalny charakter relacji ustrojowych. Celem stworzenia tych ram jest zachowanie idei demokracji, w szczególności zasady podziału władzy (równowagi instytucjonalnej) jako podstawowego jej elementu, oraz zagwarantowanie skutecznej realizacji praw wynikających z prawa UE, przede wszystkim prawa do sądu (prawa do skutecznego środka prawnego). „Prawo Unii Europejskiej zamiast wskazywać na konkretne rozwiązanie prawne czy na organ właściwy do załatwienia sprawy skupia się na określaniu wymogów, praw

${ }^{24}$ Wyrok TS dnia 30 września 2003 r. w sprawie C-224/01, Gerhard Köbler v. Republik Österreich, ECR 2003, vol. 8-9C, s. I-10239.

${ }^{25}$ Wyrok TS z dnia 1 czerwca 1999 r. w sprawie C302/97, Klaus Konle v. Republika Austriacka, ECR 1999, vol. 6, s. I-3099.

${ }^{26}$ Wyrok TS z dnia 4 lipca 2000 r. w sprawie C-424/97, Salomone Haim v. Kassenzahnärztliche Vereinigung Nordrhein, ECR 2000, vol. 7A, s. I-5123. 
i innych norm materialno-prawnych, przekazując organom Unii czuwanie nad zapewnieniem efektywności przepisom tego prawa oraz jednolitego jego stosowania" ${ }^{27}$. W związku z tym sądy krajowe, nawet w procedurze stosowania prawa unijnego, posługują się krajowymi normami przepisów postępowania ${ }^{28}$.

Jest to konsekwencja braku norm o charakterze procesowym w prawie unijnym, ponieważ przepisy prawa UE regulujące procedurę sądową należą do rzadkości. Stąd też w przypadku stosowania unijnego prawa materialnego najczęściej mówi się o autonomii procesowej sądów krajowych ${ }^{29}$. Prawo krajowe i przewidziane przez nie instytucje są podstawowymi środkami, przy wykorzystaniu których stosowane jest prawo UE, spełniające równocześnie kryterium oceny rozwiązań przyjętych przez poszczególne państwa członkowskie. Trybunał Sprawiedliwości wielokrotnie powtarzał, że przepisy postępowania nie mogą być skonstruowane $\mathrm{w}$ taki sposób, iż wykonywanie praw wynikających z prawa wspólnotowego będzie praktycznie niemożliwe ${ }^{30}$. Wymusza to przyjęcie w porządkach krajowych norm o określonym standardzie w zakresie dochodzenia roszczeń, których źródłem jest prawo UE.

Podsumowując, stwierdzić należy, że zasada podziału i równowagi władz oraz niezależności trzeciej władzy stanowią fundamenty, w granicach których może urzeczywistniać się autonomia instytucjonalna i proceduralna krajowego prawodawcy oraz w których powinna kształtować się praktyka orzecznicza. Naruszenie tych zasad jest powszechnie traktowane jako naruszenie podstaw prawnych porządku europejskiego, a skutkować może odpowiedzialnością prawną oraz politycznym wykluczeniem.

\section{Sądy jako organy stosujące prawo UE}

\subsection{Sąd krajowy powszechnym sądem wspólnotowym}

Wskazywany już wyżej obowiązek stosowania prawa UE przez każdy (krajowy) organ władzy publicznej aktualizuje się szczególnie w działalności sądów. Nie bez przyczyny w doktrynie w tym kontekście sądy krajowe stosujące to prawo określa się mianem sądów powszechnych UE ${ }^{31}$. Wyjąt-

${ }^{27}$ P. Kapusta, Sąd krajowy jako sąd unijny..., s. 230.

${ }^{28}$ Ibidem, s. 244.

${ }^{29}$ Ibidem, s. 245; A. Wyrozumska, Dochodzenie roszczeń opartych na prawie wspólnotowym przed sadami krajowymi [w:] System ochrony prawnej w Unii Europejskiej, A. Wyrozumska (red.), Warszawa 2003, s. 43; A. Wróbel, Autonomia proceduralna państw członkowskich. Zasada efektywności i zasada efektywnej ochrony sądowej w prawie Unii Europejskiej, „Ruch Prawniczy, Ekonomiczny i Socjologiczny” 2005, z. 1, s. 35.

${ }^{30}$ Wyrok TS z 9 listopada 1983 r. w sprawie C-199/83, Amministrazione delle Finanze dello Stato v. SpA San Giorgio.

${ }^{31}$ Zob. np. A. Frąckowiak-Adamska, Kompetencja..., s. 172. 
kowy status organów władzy sądowniczej znajduje uzasadnienie zwłaszcza $\mathrm{w}$ odniesieniu do tej sfery wymierzania sprawiedliwości, która związana jest $\mathrm{z}$ realizacją gwarantowanych konstytucyjnie (art. $45 \mathrm{w}$ zw. z art. 77 ust. 2 Konstytucji), jak i w unormowaniach międzynarodowych (art. 8 Konwencji o ochronie praw człowieka i podstawowych wolności ${ }^{32}$ ) prawa do sądu oraz prawa do skutecznego środka prawnego dochodzenia naruszonych wolności i praw. Ewentualne więc unikanie stosowania prawa UE przez sąd krajowy, orzekający $\mathrm{w}$ indywidualnej sprawie adresata określonych praw podmiotowych, byłoby więc kwalifikowane także jako pozbawienie tego podmiotu jednego z podstawowych środków prawnej ochrony.

\subsection{Reinterpretacja zasady podległości sędziów Konstytucji i ustawom}

W związku z tym znaczącej reinterpretacji wymaga, kluczowa z punktu widzenia działalności orzeczniczej sądów, jak i statusu prawnego samego sędziego, zasada statuowana $\mathrm{w}$ art. 178 ust. 1 Konstytucji. Zgodnie $\mathrm{z}$ jej treścią sprawujący swój urząd niezawisły sędzia jest podległy tylko Konstytucji i ustawom. Nie rozstrzygając w tym miejscu dylematu odnośnie do gwarancyjnego (wyłącznie) czy (również) kompetencyjnego waloru tego przepisu, podkreślić trzeba konieczność systemowego i bardziej uniwersalnego sposobu interpretowania wynikającej z niego normy prawnej. Uwzględnienie szczególnych reguł kolizyjnych wyrażonych przez ustrojodawcę w treści art. 91 ust. 2 i 3 Konstytucji pozwala na przyjęcie, iż podległość sędziego, o której mowa w art. 178 ust. 1 ustawy zasadniczej, nie ogranicza się jedynie do - wskazanych expressis verbis - dwóch kategorii źródeł prawa, a więc Konstytucji i ustawy. Rozciągać się ona musi także na akty normatywne, które - $\mathrm{w}$ sytuacji kolizji dekodowanych $\mathrm{z}$ nich norm $\mathrm{z}$ regulacjami ustawowymi - mają przed tymi ostatnimi pierwszeństwo. Odnosi się to więc zarówno do ratyfikowanych za zgodą wyrażoną w ustawie umów międzynarodowych (art. 91 ust. 2 Konstytucji), jak i do prawa pochodnego UE (art. 91 ust. 3 Konstytucji). W odniesieniu do kwestii podległości sędziego ustawom można więc uznać, że w treści art. 178 ust. 1 Konstytucji wskazany został jedynie najniższy - ustawowy właśnie - hierarchicznie poziom podporządkowania, nie zaś jedyny (obok Konstytucji) rodzaj aktu prawnego, na który rozciąga się zasada podległości sędziego.

Warto podkreślić w tym miejscu dodatkowe konsekwencje obowiązywania zasady wyrażonej $\mathrm{w}$ art. 178 ust. 1 Konstytucji w kontekście roli sędziego jako podmiotu przeprowadzającego incydentalną (w związku z konkretnym postępowaniem i tylko na użytek jednostkowego ustalenia podstawy prawnej rozstrzygnięcia) kontrolę hierarchicznej zgodności norm prawnych. Należy przyjąć, że unormowania art. 91 ust. 2 i 3 Konsty-

${ }^{32}$ Konwencja o ochronie praw człowieka i podstawowych wolności sporządzona w Rzymie dnia 4 listopada 1950 r., zmieniona następnie Protokołami nr 3, 5 i 8 oraz uzupełniona Protokołem nr 2, Dz.U. z 1993 r. Nr 61, poz. 284. 
tucji kreują dodatkową ${ }^{33}$, jednoznacznie zakotwiczoną w przepisach rangi konstytucyjnej podstawę dla kompetencji do odmowy zastosowania przepisu ustawy niezgodnego $\mathrm{z}$ unormowaniami zawartymi w aktach wymienionych w tych przepisach Konstytucji. Nietrudno w związku z tym zauważyć, że akceptacja prawa sędziego do incydentalnego niestosowania ustawy w tego rodzaju przypadkach kolizyjnych może być dodatkowym argumentem $\mathrm{w}$ prowadzonej w ostatnim czasie dyskusji odnośnie do analogicznego uprawnienia w sytuacji zaistnienia niezgodności normy ustawowej (mającej mieć zastosowanie w sprawie) także z Konstytucją ${ }^{34}$.

\subsection{Wykładnia prounijna a odmowa stosowania ustawy}

Nawiązanie do reguł kolizyjnych wyrażonych w art. 91 ust. 2 i 3 Konstytucji pozostaje $\mathrm{w}$ ścisłym związku $\mathrm{z}$ omawianym wyżej problemem prounijnej wykładni prawa krajowego (ustaw). Warto zauważyć, że wzgląd na normy prawa UE oraz zgodna $\mathrm{z}$ ich treścią interpretacja prawa krajowego może być $\mathrm{w}$ wielu sytuacjach swoistym kołem ratunkowym dla uniknięcia podejmowania przez sędziego bardzo poważnej w konsekwencjach decyzji o odmowie zastosowania $\mathrm{w}$ danej sprawie przepisu ustawy. W związku z tym podkreśla się $\mathrm{w}$ doktrynie, że z perspektywy prawa krajowego zastosowanie takiej wykładni zapobiega wprawdzie odmowie stosowania przepisu prawa krajowego przez sądy i zastosowania w to miejsce normy prawa UE, tym niemniej zachowanie (poprzez odpowiednią interpretację) przepisu prawa krajowego jest możliwe do granicy, którą stanowi wykładnia contra legem ${ }^{35}$. Trzeba więc podkreślić dużą odpowiedzialność złożoną na barki sędziego podejmującego się takiej oceny. Trudność sytuacji potęgować może świadomość swoistego osamotnienia sędziego krajowego w poszukiwaniu rozwiązania dylematu związanego z groźbą odmowy stosowania normy ustawowej pozostającej w kolizji z unormowaniami prawa UE. Jest to związane z niecelowością (albo też brakiem odpowiednich podstaw) poszukiwania pomocy zarówno przez pytanie prawne kierowane do Trybunału Konstytucyjnego (o czym dalej), jak i przez uruchomienie procedury pytania prejudycjalnego do TSUE.

\subsection{Pytania prejudycjalne}

Z punktu widzenia zakresu swobody interpretacyjnej i związania sędziego prawem stosowanym istotne znaczenie wydaje się mieć kompetencja do kierowania pytań prejudycjalnych do TSUE ${ }^{36}$. Pamiętać jednak należy, że

${ }^{33}$ Za źródło takiego uprawnienia można pośrednio uznać także zasady statuowane $\mathrm{w}$ art. $8 \mathrm{w}$ zw. $\mathrm{z}$ art. 9 Konstytucji.

${ }^{34} \mathrm{Na}$ ten temat ostatnio m.in. M. Gutowski, P. Kardas, Wykładnia i stosowanie prawa $w$ procesie opartym na Konstytucji, Warszawa 2017.

${ }^{35}$ K. Płeszka, Wykładnia rozszerzająca, Warszawa 2010, s. 282.

${ }^{36}$ Art. 267 Traktatu o funkcjonowaniu Unii Europejskiej, Dz.Urz. UE C 202 z 7.06.2016, s. 47. 
zasadniczo nie służy ona do uzyskania odpowiedzi na pytanie o zgodność prawa krajowego (ustawy) z prawem pochodnym UE. Formalnie rzecz biorąc, przedmiotem takiego pytania pozostaje wyłącznie kwestia ważności prawa UE bądź też problem ustalenia prawidłowej jego wykładni ${ }^{37}$. Tym samym odpowiedź na sformułowane pytanie prejudycjalne jedynie pośrednio może dostarczyć sędziemu argumentów przydatnych do rozwiązania problemu niezgodności zachodzącej między prawem krajowym (ustawą) a prawem $\mathrm{UE}^{38}$.

\section{Trybunał Konstytucyjny}

\subsection{Specyfika funkcji kontroli prawa}

Analiza stosowania prawa UE przez sąd konstytucyjny musi uwzględniać specyfikę aktywności orzeczniczej tego organu. Koncentruje się ona przede wszystkim na kontroli konstytucyjności (zgodności z ustawą zasadniczą) bądź również legalności (zgodności z podkonstytucyjnymi aktami normatywnymi) aktów prawnych. Konieczne jest więc przyjęcie w tym kontekście odmiennego od prezentowanego powyżej rozmienia samego pojęcia „stosowanie prawa”. Co do zasady prawo UE nie jest bowiem podstawą prawną rozstrzygnięć podejmowanych przez Trybunał Konstytucyjny; jedynie w przypadku pytań prejudycjalnych kierowanych przez sąd konstytucyjny do TSUE (o czym dalej) unormowania UE są normatywnym źródłem tego rodzaju kompetencji. Rozważenia wymaga natomiast dopuszczalność potraktowania prawa UE jako wzorca, względnie również przedmiotu kontroli przeprowadzanej przez Trybunał Konstytucyjny. W odróżnieniu od problemu stosowania prawa UE przez sądy rozważania dotyczące działalności orzeczniczej Trybunału Konstytucyjnego wymagają przy tym nie tylko rozgraniczenia aktów prawa pierwotnego i pochodnego UE, ale również odrębnych trybów postępowania kontrolnego wykonywanego przez sąd konstytucyjny, inicjowanych odpowiednio - wnioskiem, pytaniem prawnym lub skargą konstytucyjną.

\subsection{Prawo UE jako podstawa i przedmiot kontroli}

Dopuszczalność uznania prawa UE za element działalności orzeczniczej Trybunału Konstytucyjnego determinowana jest zarówno miejscem tego rodzaju przepisów w systemie źródeł prawa obowiązującego w RP, jak i konstytucyjnym określeniem materialnych podstaw wykonywania przez sąd konstytucyjny jego kompetencji w zakresie kontroli prawa. Jak już była

${ }^{37}$ A. Wróbel, Pytania prawne sądów państw członkowskich do Europejskiego Trybunału Sprawiedliwości (Sądu Pierwszej Instancji) [w:] Stosowanie prawa Unii Europejskiej przez sądy, A. Wróbel (red.), Kraków 2005, s. 787 i n.

${ }^{38}$ Zob. ibidem, s. 793. 
o tym mowa wyżej, rozstrzygnięcie kwestii relacji prawa UE do prawa krajowego (przede wszystkim do Konstytucji) jest przedmiotem silnych kontrowersji. Akceptacja - także przez sam Trybunał Konstytucyjny - stanowiska o zachowaniu prymatu Konstytucji w systemie źródeł prawa otwiera teoretycznie drogę do uznania prawa UE nie tylko za wzorzec kontroli prawa, ale również jej przedmiot. Oczywiście przyjęcie poglądu o dopuszczalnej weryfikacji w postępowaniu przed Trybunałem kwestii konstytucyjności unormowań prawa UE rodzi niezmiernie skomplikowane konsekwencje odnośnie do skutków prawnych orzeczeń, które stwierdzałyby tego rodzaju niezgodnośćs ${ }^{39}$.

W świetle przepisów ustawy zasadniczej normujących właściwość Trybunału Konstytucyjnego w zakresie kontroli konstytucyjności i legalności prawa dodatkowym czynnikiem determinującym omawiany tu problem stosowania prawa UE jest również sposób określenia przez ustrojodawcę aktów prawnych będących dopuszczalnym wzorcem i przedmiotem kontroli wykonywanej przez polski sąd konstytucyjny.

Ta kompilacja zewnętrznych i wewnętrznych (krajowych) czynników powoduje, że problem wykorzystania prawa UE w działaniach kontrolnych Trybunału Konstytucyjnego ma wysoce zróżnicowany i sporny co do konsekwencji charakter.

\subsection{Prawo UE jako element kontroli abstrakcyjnej}

W postępowaniu przed sądem konstytucyjnym inicjowanym za pomocą wniosków prawo UE znajduje ograniczone tylko zastosowanie jako element tak realizowanej kontroli (tzw. kontrola abstrakcyjna). Zarówno w trybie kontroli prewencyjnej, uruchamianej wyłącznie przez Prezydenta (art. 133 ust. 2 Konstytucji), jak i kontroli represyjnej, wywołanej wnioskiem uprawnionych w świetle Konstytucji podmiotów (art. 191 ust. 1 pkt 1-5), „stosowane” przez Trybunał Konstytucyjny może być jedynie prawo pierwotne UE. Jak już była o tym mowa, utożsamienie tego segmentu prawa UE z konstytucyjną kategorią ratyfikowanych w sposób złożony (za zgodą) umów międzynarodowych pozwala na jego uwzględnienie w tych przypadkach, w których ustrojodawca jednoznacznie wskazuje na objęcie kognicją Trybunału Konstytucyjnego tego rodzaju źródeł prawa. Oznacza to więc, że prawo pierwotne UE może być zarówno przedmiotem kontroli (prewencyjnej lub represyjnej), jak i podstawą tej kontroli (tylko represyjnej). Poza zakresem kontroli inicjowanej wnioskami pozostaje natomiast prawo pochodne UE, jako niemieszczące się w żadnej kategorii aktów podlegających procedurze kontroli abstrakcyjnej ${ }^{40}$.

${ }^{39}$ Zob. zwłaszcza pkt III.8 uzasadnienia wyroku TK SK 45/09.

${ }^{40} \mathrm{~W}$ szczególności brak podstaw do zaliczenia tego segmentu prawa UE do jakiejkolwiek kategorii aktów normatywnych, o których mowa w art. 188 pkt 1-3 Konstytucji. 


\subsection{Prawo UE jako przedmiot pytań prawnych i skarg konstytucyjnych}

W przeciwieństwie do procedury kontroli abstrakcyjnej, relatywnie konkretnie uregulowanej przez ustrojodawcę w zakresie rodzaju poddanych jej aktów prawnych, postępowania inicjowane pytaniami prawnymi i skargami konstytucyjnymi wydają się pozostawać bardziej otwarte z punktu widzenia dopuszczalności uwzględnienia w nich także unormowań prawa UE. Odnosi się to zwłaszcza do instytucji pytań prawnych kierowanych do Trybunału Konstytucyjnego przez sądy (art. 193 Konstytucji). Przedmiotem takiego pytania mogłoby być (przynamniej teoretycznie) zarówno prawo pierwotne UE (jako ratyfikowana za zgodą umowa międzynarodowa), jak i prawo pochodne UE (mieszczące się w zbiorczej kategorii „aktu normatywnego"). Wykluczone wydaje się jednak potraktowanie prawa pochodnego UE jako wzorca kontroli przepisów wskazywanych w pytaniu prawnym ${ }^{41}$. Specyficznie rysowałaby się natomiast sytuacja zgłaszania przez sąd wątpliwości co do zgodności ustawy zarówno z Konstytucją, jak i z prawem UE. Tego rodzaju pytanie prawne można by jednak nadal traktować jako próbę podważenia konstytucyjności kwestionowanego przepisu, przy czym wątek „unijny” mógłby służyć dodatkowemu wzmocnieniu argumentacji na rzecz (nie)zgodności kwestionowanych norm.

Z uwagi na istotę skargi konstytucyjnej jako środka ochrony wolności i praw w postępowaniu zainicjowanym skargą podstawą kontroli mogą być wyłącznie unormowania rangi konstytucyjnej. Tym samym prawo UE (zarówno pierwotne jak i pochodne), wchodząc w zakres pojęcia aktu normatywnego, o którym mowa w art. 79 ust. 1 Konstytucji, może być jedynie przedmiotem skargi konstytucyjnej ${ }^{42}$. Jest to oczywiście możliwe wówczas, gdy przepis unijny był podstawą prawną ostatecznego orzeczenia sądu lub organu administracji publicznej wydanego w sprawie skarżącego i prowadzącego do naruszenia przysługujących mu praw podstawowych.

\subsection{Domniemanie konstytucyjności a domniemanie zgodności z prawem UE}

Wynikający z pierwszeństwa prawa UE wobec ustaw, jak i zasady przychylności wobec prawa międzynarodowego (art. 9 Konstytucji) nakaz prounijniej wykładni prawa krajowego (ustaw) może też znacząco wzbogacić rozważania dotyczące zakresu zastosowania i konsekwencji zasady domniemania konstytucyjności, jakże ważnej w działalności orzeczni-

${ }^{41}$ Zgodnie z treścią art. 193 Konstytucji wzorcem kontroli inicjowanej pytaniem prawnym pozostaje bowiem wyłącznie Konstytucja, ratyfikowana umowa międzynarodowa lub ustawa. $Z$ tego też względu pozbawione podstaw byłoby kierowanie pytania prawnego w sprawie niezgodności zachodzącej między przepisem ustawy a unormowaniami prawa pochodnego UE, co zostało już wskazane w pkt 2.3.

${ }^{42}$ Zob. L. Bosek, M. Wild, Komentarz do art. 79 [w:] Konstytucja RP, t. I, Komentarz do art. 1-86, M. Safjan, L. Bosek (red.), Warszawa 2016, s. 1834-1835. 
czej $\mathrm{TK}^{43}$. Rodzi się bowiem pytanie o możliwe relacje, w jakie wchodzić mogą dwa - prima facie uzupełniające się - domniemania: konstytucyjności i „prounijności” aktu poddawanego kontroli TK. Nie wydaje się, aby problem zamknąć można wyłącznie stwierdzeniem o - będącej pochodną hierarchicznego ujęcia systemu źródeł prawa - relacji podrzędności (wynikania) tych domniemań (domniemanie zgodności z prawem UE jako element składowy domniemania konstytucyjności). Wzajemne oddziaływanie tych domniemań (ze wszystkimi tego konsekwencjami, np. w sferze ich obalania, ciężaru dowodu, konsekwencji obowiązywania) może być w konkretnych przypadkach o wiele bardziej złożone. Przykładem niech będzie wielokrotnie komentowane orzeczenie Trybunału Konstytucyjnego w sprawie niezgodności z Konstytucją przepisów ustawy implementujących europejski nakaz aresztowania ${ }^{44}$. Obydwa wskazane wyżej domniemania w odniesieniu do badanej przez TK ustawy pozostawały wówczas w kolizji. Uogólniając problem, przyjąć można, że z tego typu konfliktem sąd konstytucyjny będzie miał do czynienia zawsze wówczas, gdy zaistnieje niezgodność między unormowaniami Konstytucji i regulacjami prawa UE, a w konsekwencji także przepisami ustawowymi, implementującymi rozwiązania pochodnego prawa unijnego.

\subsection{Trybunał Konstytucyjny jako autor pytania prejudycjalnego}

Podobnie jak sądy, także Trybunał Konstytucyjny może być autorem pytania prejudycjalnego do TSUE. Warto jeszcze raz podkreślić, że przedmiotem takiego pytania nie może być - przynajmniej bezpośrednio wyrażona - kwestia zgodności aktu prawa krajowego (np. ustawy) z prawem UE. Tym samym pytanie prejudycjalne nie może być traktowane jako środek zastępujący brak kompetencji TK do przeprowadzenia kontroli, w której prawo pochodne UE byłoby wzorcem, a akt prawa krajowego (ustawa) - przedmiotem kontroli. Okoliczności formułowania pytania przez sąd konstytucyjny siłą rzeczy jednak wyznaczają takie właśnie otoczenie normatywne, $\mathrm{w}$ jakim TSUE rozstrzygać będzie sformułowane w pytaniu wątpliwości. Jak już wspomniano, podstawy prawne do kierowania pytania prejudycjalnego nie są wyrażone wprost w żadnej normie prawa krajowego, nie wskazuje ich expressis verbis ani Konstytucja, ani też - zapowiedziana w art. 197 ustawy zasadniczej - ustawa normująca organizację i tryb funkcjonowania $\mathrm{TK}^{45}$. Kompetencja ta wynika wprost z prawa UE, w związku z zasadą wyrażoną w art. 9 Konstytucji. Przykładem posłużenia się przez

${ }^{43}$ Zob. np. A. Dębowska, M. Florczak-Wątor, Domniemanie konstytucyjności ustawy w świetle orzecznictwa Trybunału Konstytucyjnego, „Przegląd Konstytucyjny” 2017, nr 2, s. 5 i n.

${ }^{44}$ Wyrok TK z dnia 27 kwietnia 2005 r., P 1/05, OTK-A 2005, nr 4, poz. 42.

${ }^{45}$ De lege lata jest to ustawa $\mathrm{z}$ dnia 30 listopada 2016 r. o organizacji i trybie postępowania przed Trybunałem Konstytucyjnym, Dz.U. poz. 2072. 
TK instytucją pytania prejudycjalnego może być zainicjowana wnioskiem Rzecznika Praw Obywatelskich sprawa niezgodności z Konstytucją przepisów ustawy o podatku VAT ${ }^{46}$. Warto jednak zauważyć, że pośrednią konsekwencją odpowiedzi wyrażonej w judykacie TSUE ${ }^{47}$ było wycofanie wniosku o kontrolę konstytucyjności ustawy, co skutkowało umorzeniem postępowania, w związku z którym TK skierował pytanie prejudycjalne ${ }^{48}$.

\section{Prawo Unii Europejskiej jako przesłanka deliktu konstytucyjnego}

W kontekście funkcjonowania Trybunału Stanu ${ }^{49}$ warto również odnotować istotną modyfikację podstaw orzekania przez ten organ władzy sądowniczej, stanowiącą kolejną konsekwencję obowiązywania norm prawa UE. Przyjmując, że egzekwowanie odpowiedzialności konstytucyjnej stanowi podstawową sferę aktywności Trybunału Stanu ${ }^{50}$, należy zauważyć, że naruszenie aktów prawa UE przez osoby określone w art. 198 Konstytucji może być także uznane za przesłankę egzekwowania tego rodzaju odpowiedzialności. Odwołując się do podobnego uzasadnienia, jak w przypadku omawianej wyżej zasady z art. 178 ust. 1 Konstytucji, należy zaaprobować taką interpretację przepisów ustawy zasadniczej konstruujących pojęcie deliktu konstytucyjnego, która uwzględni jako jego znamię nie tylko naruszenie Konstytucji lub ustawy, ale także niezgodność określonego zachowania z normami dekodowanymi z aktów mających wobec ustaw pierwszeństwo (art. 91 ust. 2 i 3 Konstytucji). Nie wydaje się, aby argumentem przeciwko takiej interpretacji mogły być wymogi określoności czynu uznawanego za delikt, rozumiane w tym przypadku jako ścisłe i dosłowne odwołanie się do treści wyłącznie i samoistnie traktowanego art. 198 Konstytucji.

\section{Zakończenie}

W naszej ocenie przeciwko sygnalizowanej na wstępie możliwości wystąpienia zjawiska swoistej emancypacji sędziego polskiego od prawa krajowego przemawiają liczne argumenty i uwarunkowania. Po pierwsze,

${ }^{46}$ Postanowienie TK z dnia 7 lipca 2015 r., K 61/13, OTK-A 2015, nr 7, poz. 103.

${ }^{47}$ Wyrok TS z dnia 7 marca 2017 r. w sprawie C-390/15, Postępowanie wszczęte na wniosek Rzecznika Praw Obywatelskich (RPO), ZOTSiS 2017, vol. 3, s. I-174.

${ }^{48}$ Postanowienie TK K 61/13.

${ }^{49}$ Pełne zastosowanie znajdują tu oczywiście wcześniejsze rozważania dotyczące zasady podległości Konstytucji i ustawom, także adresowanej do członków Trybunału Stanu (art. 199 ust. 3 Konstytucji), czy też wymogu prounijnej wykładni prawa krajowego, zob. odpowiednio pkt 2.2 i 2.3 .

${ }^{50}$ Pamiętać należy też o możliwości orzekania przez Trybunał Stanu w charakterze sądu egzekwującego odpowiedzialność za przestępstwo popełnione przez Prezydenta RP (art. 145 ust. 1 Konstytucji), a także członków Rady Ministrów (art. 156 ust. 1 Konstytucji). 
prawne - związane z licznymi wewnętrznymi (krajowymi) hamulcami, jakie wynikają zarówno z treści przepisów Konstytucji, jak i z orzecznictwa sądowego (zwłaszcza TK), przede wszystkim w odniesieniu do kwestii braku pierwszeństwa prawa UE wobec ustawy zasadniczej. Po drugie, polityczne - sugerujące konieczność uwzględnienia sfery złożonych czynników faktycznych towarzyszących stosowaniu obowiązujących unormowań. Po trzecie, socjologiczne - związane $\mathrm{z}$ indywidualnym nastawieniem samych sędziów do przyjęcia postawy aktywistycznej w zakresie „twórczego” i samodzielnego ustalenia podstawy prawnej orzekania.

Tak jak w odniesieniu do zasady niezawisłości sędziowskiej, zwłaszcza w jej aspekcie personalnym, także w przypadku mechanizmu podległości prawu wymaga on określonego nastawienia i wewnętrznego przekonania samego sędziego do wykorzystania w konkretnej sprawie kompetencji wynikających z zasad konstytucyjnych, jak i założeń prawa UE.

\section{Bibliografia}

Bosek L., Wild M., Komentarz do art. 79 [w:] Konstytucja RP, t. I, Komentarz do art. 1-86, M. Safjan, L. Bosek (red.), Warszawa 2016.

Czapliński W., Prawo wspólnotowe a prawo wewnętrzne w praktyce sądów konstytucyjnych państw członkowskich (wybrane zagadnienia), „Kwartalnik Prawa Publicznego" 2004, nr 2.

Dębowska A., Florczak-Wątor M., Domniemanie konstytucyjności ustawy w świetle orzecznictwa Trybunału Konstytucyjnego, „Przegląd Konstytucyjny” 2017, nr 2.

Frąckowiak-Adamska A., Kompetencja do niezastosowania przez sędziego krajowego przepisu ustawy niezgodnego z Konstytucja lub prawem wspólnotowym [w:] Stosowanie prawa wspólnotowego $w$ prawie wewnętrznym $z$ uwzględnieniem prawa polskiego, D. Kornobis-Romanowska (red.), Warszawa 2004.

Gutowski M., Kardas P., Wykładnia i stosowanie prawa w procesie opartym na Konstytucji, Warszawa 2017.

Kalisz A., Muliticentryczność systemu prawa polskiego a działalność orzecznicza Europejskiego Trybunału Sprawiedliwości i Europejskiego Trybunału Praw Człowieka, „Ruch Prawniczy, Ekonomiczny i Socjologiczny” 2007, rok LXIX, z. 4.

Kapusta P., Sad krajowy jako sąd unijny [w:] Zasada pierwszeństwa prawa Unii Europejskiej w praktyce działania organów władzy publicznej RP, M. Jabłoński, S. Jarosz-Żukowska (red.), Wrocław 2015, http://www.repozytorium.uni.wroc. pl/Content/64532/13_Piotr_Kapusta.pdf.

Łętowska E., Multicentryczność współczesnego systemu prawa i wykładnia jej przyjazna [w:] Rozprawy prawnicze. Ksiegga pamiątkowa Profesora Maksymiliana Pazdana, L. Ogiegło, W. Popiołek, M. Szpunar (red.), Kraków 2002.

Mik C., Powierzenie Unii Europejskiej władzy przez państwa członkowskie i jego podstawowe konsekwencje prawne [w:] Suwerenność i ponadnarodowość a integracja europejska, J. Kranz (red.), Warszawa 2006.

Pawłowicz K., Konstytucja europejska - źródło nieustających emocji. Nie ma praw oczywistych - polemika, „Rzeczpospolita” z 28 czerwca 2004 r.

Płeszka K., Wykładnia rozszerzająca, Warszawa 2010. 
Wasilkowski A., Miejsce umów międzynarodowych wedle nowej Konstytucji RP, „Przegląd Legislacyjny” 1997, nr 2.

Wróbel A., Autonomia proceduralna państw członkowskich. Zasada efektywności i zasada efektywnej ochrony sądowej w prawie Unii Europejskiej, „Ruch Prawniczy, Ekonomiczny i Socjologiczny" 2005, z. 1.

Wróbel A., Pytania prawne sądów państw członkowskich do Europejskiego Trybunatu Sprawiedliwości (Sądu Pierwszej Instancji) [w:] Stosowanie prawa Unii Europejskiej przez sądy, A. Wróbel (red.), Kraków 2005.

Wróblewski J., Sądowe stosowanie prawa, Warszawa 1988.

Wyrozumska A., Dochodzenie roszczeń opartych na prawie wspólnotowym przed sądami krajowymi [w:] System ochrony prawnej w Unii Europejskiej, A. Wyrozumska (red.), Warszawa 2003.

\section{Akty prawne}

Traktat o funkcjonowaniu Unii Europejskiej, Dz.Urz. UE C 202 z 7.06.2016, s. 47.

Konwencja o ochronie praw człowieka i podstawowych wolności sporządzona w Rzymie dnia 4 listopada 1950 r., zmieniona następnie Protokołami nr 3, 5 i 8 oraz uzupełniona Protokołem nr 2, Dz.U. z 1993 r. Nr 61, poz. 284.

Konstytucja Rzeczypospolitej Polskiej z dnia 2 kwietnia 1997 r., Dz.U. Nr 78, poz. 483 ze zm.

Ustawa z dnia 30 listopada 2016 r. o organizacji i trybie postępowania przed Trybunałem Konstytucyjnym, Dz.U. poz. 2072.

\section{Orzecznictwo}

Wyrok TS z dnia 5 lutego 1963 r. w sprawie 26/62, N.V. Algemene Transport-en Expeditie Onderneming van Gend \& Loos v. Nederlandse administratie der belastingen, ECR 1963, s. 1.

Wyrok TS z dnia 15 lipca 1964 r. w sprawie 6/64, Flaminio Costa v. E.N.E.L., ECR 1964, s. 614.

Wyrok z dnia 17 grudnia 1970 r. w sprawie 11/70, Internationale Handelsgesellscha$f t \mathrm{mbH}$ v. Einfuhr- und Vorratsstelle für Getreide und Futtermittel, ECR 1970, vol. 2, s. 112.

Wyrok z dnia 9 marca 1978 r. w sprawie 106/77, Amministrazione delle Finanze dello Stato v. Simmenthal S.p.A., ECR 1978, vol. 3, s. 629.

Wyrok TS z dnia 19 listopada 1991 r. w sprawach C6/90 i C9/90, Andrea Francovich i inni v. Republika Włoska, ECR 1991, vol. 9, s. I-5357.

Wyrok TS z dnia 14 lipca 1994 r. w sprawie C-91/92, Paola Faccini Dori v. Recreb Srl, ECR 1994, vol. 7, s. I-3325.

Wyrok TS z dnia 5 marca 1996 r. w sprawach połączonych C46/93 i C48/93, Brasserie du Pecheur SA v. Republika Federalna Niemiec $i$ The Queen v. Secretary of State for Transport, ex parte Factortame Ltd i inni, ECR 1996, vol. 3, s. I-1029.

Wyrok TS z dnia 1 czerwca 1999 r. w sprawie C302/97, Klaus Konle v. Republika Austriacka, ECR 1999, vol. 6, s. I-3099.

Wyrok TS z dnia 4 lipca 2000 r. w sprawie C-424/97, Salomone Haim v. Kassenzahnärztliche Vereinigung Nordrhein, ECR 2000, vol. 7A, s. I-5123.

Wyrok TS z dnia 30 września 2003 r. w sprawie C-224/01, Gerhard Köbler v. Republik Österreich, ECR 2003, vol. 8-9C, s. I-10239. 
Wyrok TS z dnia 19 listopada 2009 r. w sprawie C-314/08, Krzysztof Filipiak v. Dyrektor Izby Skarbowej w Poznaniu, ECR 2009, vol. 11, s. I-11049.

Wyrok TS z dnia 7 marca 2017 r. w sprawie C-390/15, Postepowanie wszczęte na wniosek Rzecznika Praw Obywatelskich (RPO), ZOTSiS 2017, vol. 3, s. I-174.

Wyrok Federalnego Trybunału Konstytucyjnego (BVG) z dnia 28 maja 1974 r. w sprawie 37/271, Solange I.

Wyrok Federalnego Trybunału Konstytucyjnego (BVG) z dnia 26 października 1986 r. w sprawie 73/339, Solange II.

Wyrok Federalnego Trybunału Konstytucyjnego (BVG) z dnia 12 października 1993 r. w sprawie 89/155, Maastricht.

Wyrok Federalnego Trybunału Konstytucyjnego (BVG) z dnia 30 czerwca 2009 r. w sprawie 2/08, Lissabon-Urteil.

Wyrok Federalnego Trybunału Konstytucyjnego (BVG) z dnia 6 lipca 2010 r. w sprawie 2661/06, Honeywell.

Wyrok TK z dnia 27 kwietnia 2005 r., P 1/05, OTK-A 2005, nr 4, poz. 42.

Wyrok TK z dnia 11 maja 2005 r., K 18/04, Dz.U. Nr 86, poz. 744.

Wyrok TK z dnia 24 listopada 2010 r., K 32/09, Dz.U. Nr 229, poz. 1506.

Wyrok TK z dnia 16 listopada 2011 r., SK 45/09, Dz.U. Nr 254, poz. 1530.

Postanowienie TK z dnia 7 lipca 2015 r., K 61/13, OTK-A 2015, nr 7, poz. 103.

Wyrok SN z dnia 29 listopada 2005 r., II PK 100/05, OSNP 2006, nr 19-20, poz. 299.

Wyrok SN z dnia 7 lutego 2007 r., I PK 269/06, OSP 2009, z. 1, poz. 11.

Wyrok SN z dnia 11 grudnia 2014 r., I PK 120/14, LEX nr 1628903.

Streszczenie

Artykuł poświęcony został analizie wpływu regulacji (zasad) konstytucyjnych na proces stosowania prawa UE przez organy władzy sądowniczej w RP - sądy i trybunały. Podjęto próbę odpowiedzi na pytanie o zakres swobody sędziego w stosowaniu prawa krajowego i prawa UE. Istotne znaczenie ma tu przede wszystkim rozstrzygnięcie kwestii relacji prawa UE do prawa krajowego, w pierwszym zaś rzędzie do Konstytucji. Jedną z konsekwencji multicentryczności systemu źródeł prawa, jak również zasady przychylności RP dla prawa międzynarodowego (art. 9 Konstytucji) jest obowiązek stosowania norm praw UE, a także prounijnej wykładni prawa krajowego przez wszystkie organy władzy publicznej. W kontekście działalności orzeczniczej sądów obowiązywanie prawa UE istotnie wpływa na sposób interpretacji zasady podległości sędziego Konstytucji i ustawom, jak również na zakres swobody odnośnie do samodzielnego określenia przez sędziego podstawy orzekania. Reguły kolizyjne wyrażone w art. 91 ust. 2 i 3 Konstytucji jednoznacznie upoważniają także do odmowy stosowania ustaw pozostających w nieusuwalnej sprzeczności z przepisami prawa pierwotnego i pochodnego UE. Prawo UE może być także elementem kontroli wykonywanej przez Trybunał Konstytucyjny. W ograniczonym zakresie dotyczy to kontroli abstrakcyjnej, jest też możliwe uczynienie go przedmiotem kontroli inicjowanej pytaniami prawnymi i skargami konstytucyjnymi. Obowiązywanie prawa UE może wpływać na konstrukcję deliktu konstytucyjnego, którego popełnienie wiąże się z odpowiedzialnością egzekwo- 
waną przez Trybunał Stanu. W konkluzji wskazane zostały liczne (prawne, polityczne i socjologiczne) ograniczenia dla zjawiska emancypacji sędziów orzekających w organach władzy sądowniczej w RP z bezwzględnego związania prawem krajowym.

Słowa kluczowe: prawo UE, nadrzędność Konstytucji, podległość sędziów Konstytucji i ustawom, prounijna wykładnia, kontrola konstytucyjności, delikt konstytucyjny

\title{
The Constitutional Determinants of the Application of European Union Law by the Polish Judiciary
}

\begin{abstract}
This article analyses the impact of constitutional regulations (principles) on the process of EU law application by the judicial authorities in Poland, that is courts and tribunals. An attempt is made to answer the question regarding the limits of the judge's freedom in the application of national and EU laws. Of particular importance is the determination of the relation between EU law and national law, above all the Constitution. One of the consequence of the multicentricity of the system of sources of law, as well as of the principle of Poland's favouring international law (Article 9 of the Constitution), is the obligation to apply EU legal standards and EU-friendly interpretation of national law by all public authority bodies. As regards the adjudicating activity of the courts, the fact of the binding nature of EU law has a considerable impact on how the principles of the judge's subordination to the Constitution and acts of law are interpreter as well on the range of freedom as regards the judge's power to independently determine the basis for adjudication. The conflict-of-laws principles expressed in Article 91(2) and Article 91(3) of the Constitution unambiguously authorise the judge to also refuse to apply acts of law irremovably contradicting provisions of EU primary and secondary law. EU law may also be a factor in the review function of the Constitutional Court. In a limited scope this pertains to abstract review, it is also possible to involve EU law in review triggered by legal questions and constitutional complaints. The fact that EU law is binding may also influence the structure of the constitutional tort, commitment of which entails liability enforced by the State Tribunal. The conclusion includes a number of (legal, political and sociological) limitations of the freedom enjoyed by judges adjudicating in the Polish judicial authorities as regards the loosening of their being absolutely bound by national legislation.
\end{abstract}

Keywords: EU law, the primacy of the Constitution, the judge's subordination to the Constitution and acts of law, EU-friendly interpretation, constitutional review, constitutional tort 